\title{
ANALISIS INFLASI DI SUMATERA UTARA: SUATU MODEL ERROR CORRECTION (ECM)
}

\author{
Hafsyah Aprillia \\ Mahasiswa PPs Ilmu Ekonomi Unimed \\ Jl. Williem Iskandar Ps. V. Medan
}

\begin{abstract}
The research was conducted to determine the effect of economic variables that can explain the change or variation in the rate of inflation in the Consumer Price Index (CPI) as the dependent variable. The explanatory variables (independent) were used as controls are SBI, the nominal interest rate spread (SBI) and the value of the rupiah against the U.S. dollar. Based on these results, according to the specific purpose of the model equations II, suggested economic actors can use SBI interest rate spread as an indicator of variations in the CPI inflation rate at intervals of 8 and 12 months, with a note that the obtained level of explanation has not shown that the optimal value.
\end{abstract}

Key words: Inflation, Interest Rate, Exchange Rate, Error Correction Model (ECM)

\section{PENDAHULUAN}

7 nflasi telah menjadi masalah besar dalam perekonomian Indonesia, banyak faktor yang mempengaruhi laju inflasi sehingga laju inflasi tidak seluruhnya berada dalam kendali bank sentral. Secara teori, inflasi merupakan resultan interaksi antara permintaan dan penawaran agregat perekonomian. Sementara itu kebijakan moneter pada dasarnya lebih efektif untuk mengendalikan tekanan inflasi yang berasal dari sisi permintaan agregat. Untuk kasus Indonesia tidak terkecuali daerah Sumatera Utara, upaya pengendalian inflasi merupakan persoalan yang cukup berat untuk dilaksanakan secara optimal. Hal ini terutama terkait dengan belum normalnya kondisi sektor perbankan sebagai channel utama yang menghubungkan sektor moneter dengan sektor riil. Keadaan ini menyebabkan masih tingginya ketidakpastian yang melingkupi transmisi kebijakan moneter di Indonesia.

Inflasi di Indonesia pernah mencapai titik yang tertinggi yaitu pada pertengahan dasawarsa 1960-an dimana terjadi hyper inflasi yang melanda perekonomian nasional dengan laju inflasi mencapai 650 persen. Hal tersebut terutama disebabkan oleh defisit anggaran belanja pemerintah yang kemudian dibiayai Bank Indonesia dalam bentuk pencetakan uang. Laju inflasi di Sumatera Utara selama tahun 1998-2010 menunjukkan adanya fluktuasi yang bervariasi dari waktu ke waktu yang disebabkan 
oleh faktor yang berbeda. Pada periode awal 1998, tingkat inflasi tinggi sebesar 83,56 persen, lebih tinggi dari angka nasional yang mencapai 77,63 persen. Tingkat inflasi yang tinggi ini karena dampak dari krisis moneter yang terjadi pada tahun 1997. Selama tahun 1999-2000, tingkat inflasi Sumatera Utara mengalami penurunan dan penurunan yang tertinggi terjadi pada bulan Januari 1999 yaitu sebesar 1,37 persen. Nilai tertinggi pada tahun 1998 merupakan dampak dari merosotnya nilai tukar rupiah terhadap dolar dan faktor sosial politik yang tidak aman, sehingga mengakibatkan harga barang dan jasa terus meningkat tajam sampai akhir tahun 1998.

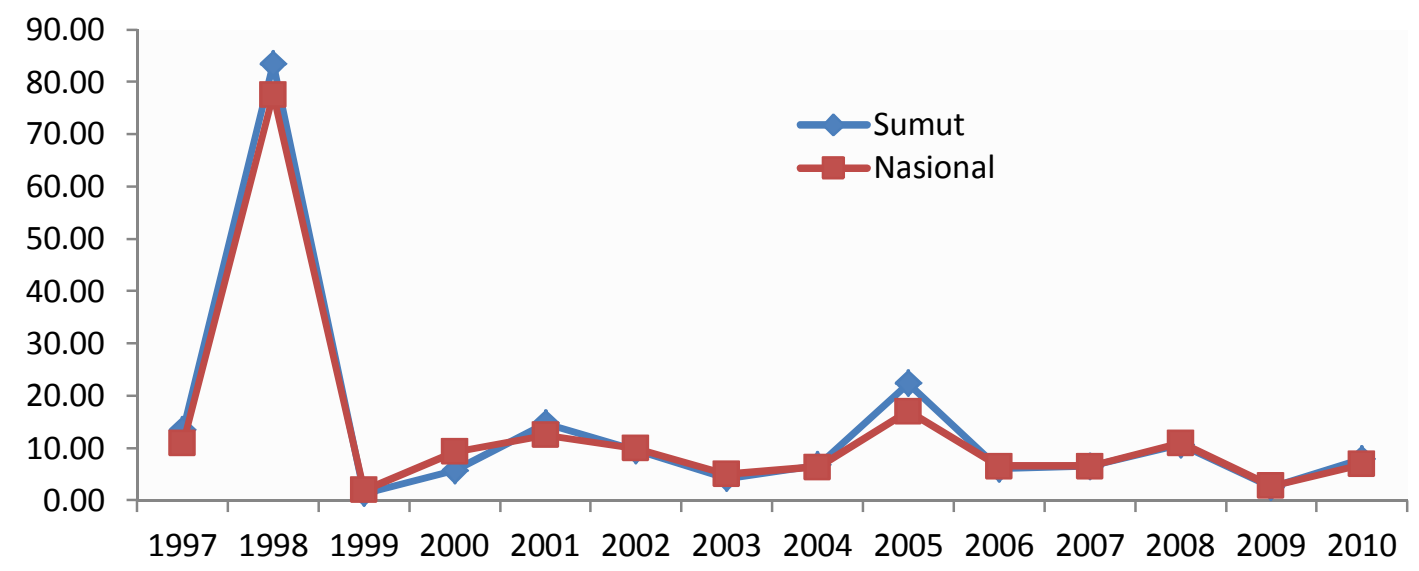

Gambar 1. Laju Inflasi Tahunan di Sumatera Utara dan Indonesia Kurun Waktu 1997 2010

Laju inflasi tahunan dari tahun 2000-2004 sudah mulai stabil dimana angkanya yang berada dibawah dua digit. Inflasi tahun 2000 jika dibandingkan dengan inflasi tahun 1999 meningkat secara tajam yaitu dari 1,37 persen menjadi 5,73 persen. Peningkatan laju inflasi ini diantaranya disebabkan adanya kenaikan tarif angkutan per 1 September 2000, kenaikan BBM per Oktober 2000, Bulan Puasa/Ramadhan (November 2000), Natal dan Lebaran (Desember 2000). Secara umum pada tahun 2000-2005, inflasi terus terjadi dengan nilai yang terbilang tinggi, yaitu dengan rata-rata mencapai 10 persen.

Pada tahun 2005 laju inflasi kembali naik mencapai 22,41 persen. Ini adalah inflasi tertinggi pasca krisis moneter Indonesia (1997/1998). Penyesuaian terhadap kenaikan harga bahan bakar minyak (BBM) diperkirakan menjadi faktor utama tingginya inflasi tahun 2005. Tingginya harga minyak di pasar internasional menyebabkan pemerintah berusaha untuk menghapuskan subsidi BBM. Jika melihat inflasi bulanan pada tahun 2005 yang tertinggi terjadi pada bulan Oktober yaitu sebesar 11,56 persen (Gambar 1).

Laju inflasi selama tahun 2006-2007 menunjukkan perkembangan yang relatif stabil yaitu berkisar pada 6 persen. Laju inflasi tahun 2006 sebesar 6,11 persen sedangkan pada tahun 2007 sebesar 6,60 persen. Laju inflasi bulanan tahun 2006 dan 2007 menunjukkan dalam kondisi yang stabil yaitu dibawah 2 persen. Tekanan inflasi yang cukup tinggi terjadi di bulan Desember tahun 2006.

Tabel 1. Laju Inflasi Tahunan 4 Kota di Sumatera Utara dan Nasional Tahun 1997-2010 


\begin{tabular}{|c|c|c|c|c|c|c|}
\hline Tahun & Medan & P.Siantar & Sibolga & $\begin{array}{c}\text { Padang } \\
\text { Sidempuan }\end{array}$ & Sumut & Nasional \\
\hline (1) & (2) & (3) & (4) & (5) & (6) & (7) \\
\hline 1997 & 13,10 & 15,14 & 14,60 & 16,84 & 13,54 & 11,05 \\
\hline 1998 & 83,81 & 80,23 & 85,01 & 85,72 & 83,56 & 77,63 \\
\hline 1999 & 1,68 & $-0,54$ & 1,65 & $-0,14$ & 1,37 & 2,01 \\
\hline 2000 & 5,90 & 4,67 & 6,95 & 3,95 & 5,73 & 9,35 \\
\hline 2001 & 15,50 & 13,55 & 8,66 & 9,84 & 14,78 & 12,55 \\
\hline 2002 & 9,49 & 9,41 & 11,58 & 10,18 & 9,59 & 10,03 \\
\hline 2003 & 4,46 & 2,51 & 3,94 & 4,07 & 4,23 & 5,06 \\
\hline 2004 & 6,64 & 7,31 & 6,64 & 8,99 & 6,80 & 6,40 \\
\hline 2005 & 22,91 & 19,67 & 22,39 & 18,47 & 22,41 & 17,11 \\
\hline 2006 & 5,97 & 6,06 & 5,03 & 10,02 & 6,11 & 6,60 \\
\hline 2007 & 6,42 & 8,37 & 7,13 & 5,87 & 6,60 & 6,59 \\
\hline 2008 & 10,63 & 10,16 & 12,36 & 12,34 & 10,72 & 11,06 \\
\hline 2009 & 2,69 & 2,72 & 1,59 & 1,87 & 2,61 & 2,78 \\
\hline 2010 & 7,65 & 9,68 & 11,83 & 7,42 & 8,00 & 6,96 \\
\hline
\end{tabular}

Sumber: BPS Provinsi Sumatera Utara

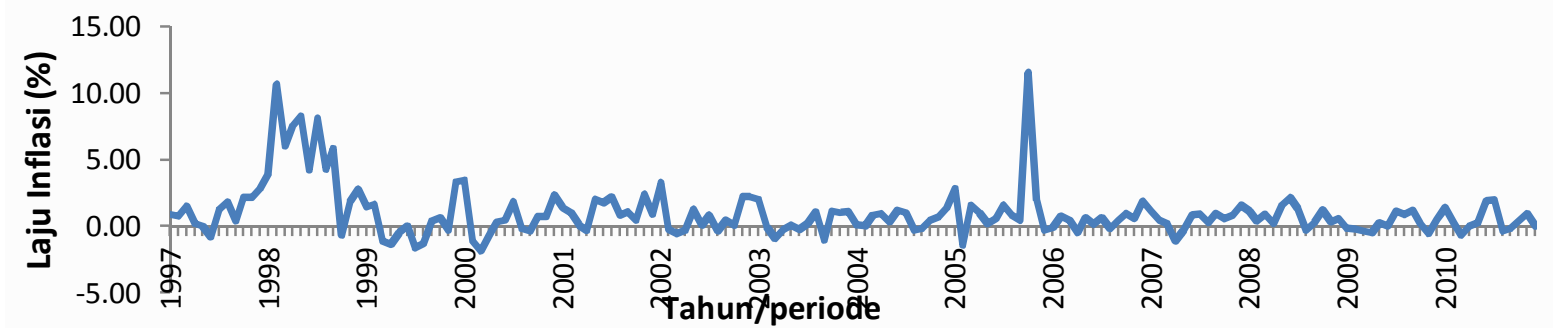

Sumber : BPS (diolah)

Gambar 1. Laju Inflasi Bulanan di Sumatera Utara Tahun 1997-2010

Penurunan laju inflasi dikarenakan adanya penundaan kenaikan tarif dasar listrik oleh pemerintah. Laju inflasi bulanan di tahun 2007 juga menunjukkan kondisi yang sama dengan tahun 2006 dimana nilainya masih di bawah 2,00 persen. Menjelang akhir tahun 2007, inflasi mengalami kenaikan yaitu dari 1,58 persen. Inflasi tahun 2008 mencapai 10,72 persen naik sebesar 4,12 persen bila dibandingkan dengan tahun 2007. Pada Januari tahun 2008 laju inflasi sebesar 1,14 persen. Inflasi bulanan tertinggi dicapai pada bulan Juni yaitu sebesar 2,18 persen.

Inflasi pada tahun 2008 selain dipengaruhi oleh krisis keuangan global, juga dipengaruhi oleh inflasi harga yang diatur pemerintah dan bahan makanan yang bergejolak. Laju inflasi tahun 2009-2010 menunjukkan kondisi yang relatif stabil dimana pada tahun 2009 inflasi sebesar 2,61 persen dan tahun 2010 sebesar 8,00 persen. Untuk laju inflasi bulanan selama tahun 2009, nilainya masih dibawah 1 persen dan yang tertinggi dicapai pada bulan September sebesar 1,20 persen.Selama tahun 2009, sempat terjadi deflasi yaitu pada bulan Januari, Februari, Maret, April dan November dengan deflasi terbesar terjadi di bulan November sebesar 0,52 persen. 
Laju inflasi bulanan di tahun 2010 masih dibawah 1 persen dan sempat mengalami inflasi tinggi yaitu sebesar 2,00 persen pada bulan Juli. Pada bulan Maret juga sempat terjadi deflasi sebesar 0.64 persen. Inflasi tahun 2010 tersebut melampaui target yang ditetapkan oleh Bank Indonesia di awal tahun yaitu $5 \pm 1$ persen dan juga melampau target inflasi pemerintah sebesar 5,3 persen. Perkembangan model Kebijakan Moneter pada dasarnya telah mencapai tahapan dimana secara umum sebagian besar negara mencoba beralih untuk berkonsentrasi menjaga stabilitas tingkat harga. Target tersebut ditetapkan atau dipilih mengingat fenomena inflasi tinggi (hiperinflasi) dalam perekonomian memiliki banyak sisi negatif, misalnya, sektor keuangan akan mengalami ketidakstabilan sehingga keputusan penanaman investasi dalam sektor ini terhambat, inflasi meningkatkan ongkos produksi yang berasal dari kenaikan harga faktor produksi, hilangnya pendapatan riil masyarakat karena kenaikan harga barang dan jasa, keseimbangan uang riil yang dipegang masyarakat menurun atau menjadi lebih rendah.

Kebijakan moneter sebagai salah satu alat untuk menjaga stabilitas harga, juga memiliki penyimpangan (deviasi) dalam kebijakan yang menyangkut inflasi dan penyimpangan tersebut tidak dapat diketahui secara pasti, sehingga ketidakpastian itu pada akhirnya dapat mempengaruhi efektifitas kebijakan moneter. Kondisi ketidakpastian itu tentu merugikan pasar, khususnya pelaku ekonomi yang sangat dipengaruhi oleh tingkat inflasi. Mulai dari produsen, konsumen, debitur, kreditur maupun praktisi pasar keuangan selalu memperhatikan pergerakan inflasi dan perkiraan inflasi dimasa mendatang sebagai pertimbangan pembuatan keputusan.

Model kebijakan Bank Indonesia setelah penetapan UU No 23 tahun 1999 khususnya pasal 10, mengharuskan Bank Indonesia melakukan penargetan tingkat inflasi dengan cara mengumumkan sasaran-sasaran moneter dalam mencapai target inflasi. Pertimbangan yang menjadi latar belakang penargetan inflasi sebagai kebijakan Bank Indonesia adalah (Triono Widodo dan Erwin Haryono, 2002), tuntutan masyarakat terhadap peningkatan kompetensi Bank Indonesia dalam mengendalikan inflasi dan nilai tukar, perubahan cepat dalam sistem ekonomi dan keuangan global berpengaruh besar terhadap sistem ekonomi-keuangan dalam negeri yang mendorong melemahnya hubungan antara besaran moneter dengan sektor riil, kondisi krisis menyebabkan besarnya faktor non-moneter yang mempengaruhi pergerakan inflasi dan nilai tukar, framework kebijakan yang telah ada tidak dapat secara langsung merespons deviasi perkiraan inflasi terhadap targetnya.

Upaya Bank Indonesia untuk mencapai tujuan tersebut adalah menetapkan sasaran inflasi dengan cara yang tepat melalui pertimbangan-pertimbangan kondisi makroekonomi. Penetapan sasaran inflasi ditujukan untuk mendukung upaya pencapaian sasaran inflasi melalui pembentukan ekspektasi masyarakat dengan penerapan kebijakan moneter yang tetap mendukung proses pemulihan ekonomi. Salah satu cara yang digunakan untuk tetap mendukung pemulihan ekonomi tersebut adalah melalui penentuan tingkat suku bunga nominal (transmisi moneter melalui jalur suku bunga), yang aman bagi perekonomian secara makro. Untuk itu berbagai aspek penting dikaji dalam penetapan sasaran inflasi dan level dari sasaran inflasi yang akan 
dicapai, sebagai contoh melalui transmisi moneter nilai tukar, agregat moneter, ekspektasi inflasi dan transmisi melalui tingkat suku bunga nominal (tingkat suku bunga Sertifiikat Bank Indonesia). Namun demikian, tingginya variabilitas pergerakan harga relatif diantara komponen barang yang tercakup dalam komponen perhitungan Indeks Harga Konsumen, serta tingginya pengaruh non fundamental (seperti pengaruh musiman dan dampak penerapan kebijakan pemerintah di bidang harga atau pendapatan dalam perkembangan inflasi di Indonesia), menyebabkan pergerakan laju inflasi Indeks Harga Konsumen seringkali tidak mencerminkan perkembangan inflasi yang sesungguhnya.

Framework penargetan inflasi (Inflation Targeting) dengan suku bunga sebagai sasaran operasional telah disetujui dan disahkan oleh Rapat Dewan Gubernur Bank Indonesia tanggal 12 Maret 2002, untuk segera diaplikasikan di lingkungan Bank Indonesia. Dengan demikian, untuk jangka waktu selanjutnya masyarakat diharapkan menggunakan sasaran inflasi sebagai patokan (anchor) dalam kegiatan ekonomi, sehingga ekspektasi pelaku ekonomi terhadap inflasi lebih mudah dipengaruhi oleh sasaran inflasi yang ditetapkan oleh Bank Indonesia. Indeks Harga Konsumen ditetapkan sebagai sasaran inflasi walaupun Bank Indonesia harus menanggung konsekuensi rendahnya tingkat prediktabilitas dan kontrolabilitas jenis inflasi ini, mengingat banyaknya faktor gangguan (shock) yang terdapat di dalamnya.

Secara umum inflasi dipengaruhi secara langsung maupun tidak langsung oleh variabel-variabel ekonomi antara lain dari dalam dan sisi luar Bank Sentral. Dari sisi Bank Sentral, inflasi dapat dipengaruhi melalui kebijakan moneter melalui penetapan tingkat suku bunga nominal atau penentuan jumlah penawaran uang (berkaitan dengan keseimbangan uang riil yang akan mempengaruhi tingkat harga). Faktor diluar Bank Sentral yang mempengaruhi tingkat inflasi adalah nilai tukar mata uang riil, permintaan agregat terhadap barang atau jasa dan jumlah produksi aktual (penawaran) barang atau jasa dalam negeri. Secara hirarkis, variabel-variabel tersebut terkait satu sama lain dalam suatu struktur perekonomian terbuka, atau dalam kerangka perekonmian Indonesia adalah perekonomian terbuka kecil.

Berangkat dari pemikiran tersebut, penelitian ini mencoba untuk mengetahui perilaku variabel-variabel yang mempengaruhi inflasi, baik secara langsung maupun tidak langsung, dengan mengacu pada kondisi atau kerangka ekonomi yang relevan. Penelitian ini memasukkan variabel spread suku bunga nominal guna mengetahui tingkat prediktabilitas indikator ini terhadap tingkat inflasi beberapa periode waktu mendatang. Tujuan dari penggunaan variabel spread suku bunga adalah untuk mencari apakah variabel tersebut mengandung informasi yang dapat digunakan pelaku ekonomi untuk memperkirakan dan membentuk ekspektasi inflasi di masa mendatang, dengan mengacu pada teori Rational Expectataion yang berkembang saat ini, sedangkan variabel kurs, output gap dan tingkat inflasi periode sebelumnya, ditujukan untuk mengetahui pengaruh variabel-variabel tersebut terhadap tingkat inflasi, dengan mengacu pada pembentukan ekspektasi secara forward dan bacward looking.

\section{METODOLOGI}


Untuk membuktikan hipotesis 1 dan 2, maka digunakan model ekonometrika regresi linear berganda dengan metode ECM (Error Correction Model).

Hipotesis 1 menggunakan model sebagai berikut; Persamaan I:

$$
\begin{aligned}
& D I N F_{t}=\beta_{0}+\beta_{2} D S B I_{t}+\beta_{1} D S P R E A D_{t}+\beta_{3} D K U R S_{t}+\beta_{4} S B I(-1)+ \\
& \beta_{5} \operatorname{SPREAD}(-1)+\beta_{6} \operatorname{KURS}(-1)+\beta_{7} E C T_{t}
\end{aligned}
$$

Hipotesis 2 menggunakan model sebagai berikut; Persamaan II:

$$
I N F_{t+n}=\alpha_{0}+\alpha_{1} D S P R E A D_{t}+\alpha_{2} \operatorname{SPREAD}(-1)+\alpha_{3} E C T_{2}
$$

Dimana :

INF $\quad$ : Tingkat inflasi pada periode waktu $t+k$

SBI : Tingkat suku bunga nominal jangka pendek (waktu 1 bulan)

SPREAD : Spread suku bunga nominal; (SBI3 - SBI)

KURS : Nilai tukar Rupiah terhadap dollar AS

SBI3 : Tingkat suku bunga nominal jangka panjang (waktu 3 bulan)

ECT : Error corection term 1

$$
\begin{aligned}
& \mathrm{ECT}_{1}=S B I(-1)+\operatorname{SPREAD}(-1)+K U R S(-1)-\operatorname{INF}(-1) \\
& \mathrm{ECT}_{2}=\operatorname{SPREAD}(-1)-I N F_{t+n-1}
\end{aligned}
$$

$$
\begin{array}{ll}
\alpha_{0}, \beta_{0} & : \text { Koefisien intersep } \\
\alpha_{1}, \alpha_{2}, \alpha_{3}, \beta_{1}, \beta_{2}, \beta_{3}, \ldots \ldots \beta_{10} & : \text { Koefisien regresi } \\
\mathrm{N} & : \text { menunjukkan rentang waktu/lag. }(m>n)
\end{array}
$$

\section{HASIL DAN PEMBAHASAN}

\section{Hasil Analisis}

Untuk mengetahui bagaimana hubungan antar variabel dependen dan independen, serta melakukan pembuktiaan atas hipotesis yang diajukan dan telah dikemukakan, maka perlu dilakukan suatu uji empiris. Dalam penelitian ini, pengujian dilakukan dengan menggunakan alat analisis Error Correction Model (ECM) atau model koreksi kesalahan, dimana data yang digunakan sebagai bahan analisis meliputi data runtun waktu (time series) mulai Januari 2003 sampai Desember 2010. Variabel makro yang dianalisis meliputi variabel independen; tingkat suku bunga SBI, spread suku bunga SBI dan nilai tukar rupiah, sedangkan variabel dependen adalah tingkat inflasi. Melalui analisis ECM, hubungan antar variabel tersebut dapat terlihat dari hasil regresi dengan model dinamis. Sebelum dilakukan regresi dengan model dinamis ECM terlebih dahulu dilakukan beberapa uji pendahuluan yang meliputi uji MWD, uji akar unit dan uji kointegrasi. 


\section{Regresi dengan ECM Model}

Fungsi utama uji MWD adalah untuk mengetahui model persamaan terbaik yang dapat digunakan sebagai analisis empiris. Penelitian ini menganalisis peubah-peubah bebas yang dianggap berpengaruh terhadap inflasi. Pengolahan data menggunakan software Eviews 7. menghasilkan model sebagai berikut:

Persamaan I:

DINF $F_{t}=-04171+1,56 D S B I-0,03 D S P R E A D-0,001 D K U R S-0,92 S B I_{(-1)}-1,63 S P R E D(-1)-0,92 K U R S(-$ 1) $+0,92 E C T 01+U_{t}$

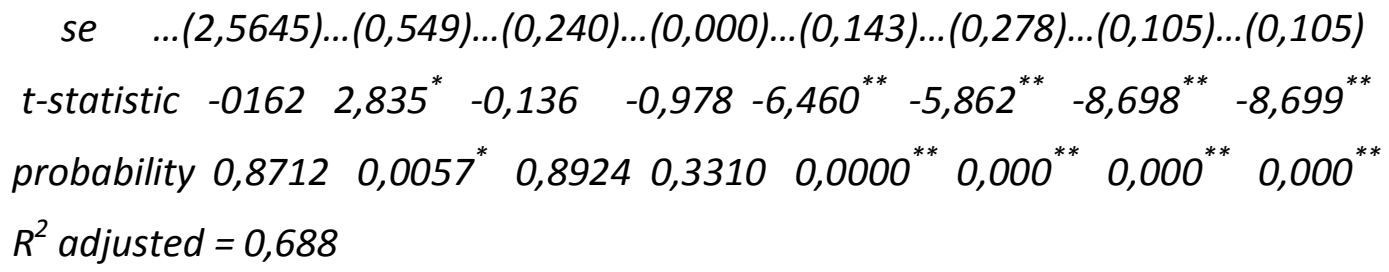

Dari hasil tersebut dapat dilihat bahwa nilai probabilitas dengan menggunakan persamaan linear menunjukkan nilai yang signifikan pada tingkat kesalahan $5 \%$, yaitu ECT menunjukkan nilai 0,0000 , artinya $\mathrm{H}_{0}$ yang menyatakan bahwa model ECM linear merupakan model terbaik ditolak.

\section{Uji Akar Unit dan Uji Derajat Integrasi}

Dari hasil uji derajat integrasi tersebut diperoleh hasil nilai hitung SBI_1, SPREAD dan KURS pada orde satu [I(1)], dimana pada orde ini ketiga variabel tersebut menunjukkan stasioneritas pada nilai kritis DF dan ADF $10 \%$.

\section{Uji Kointegrasi}

Dari hasil regresi kointegrasi sebagaimana ditunjukkan pada lampiran didapatkan nilai residualnya, kemudian nilai residu tersebut diuji menggunakan metode DF dan ADF untuk melihat apakah nilai residual tersebut stasioner atau tidak, pengujian ini sangat penting apabila model dinamis akan dikembangkan. menunjukkan bahwa nilai residu yang didapat ternyata stasioner pada orde 0 , hal ini terlihat dari nilai hitung mutlak DF dan ADF yang lebih besar dari nilai kritis mutlak pada $\alpha 10 \%$, maka langkah selanjutnya adalah melakukan analisis regresi ECM.

\section{Hasil Estimasi Model Dinamik Error Correction Model (ECM)}

Koefisien yang menjadi kunci dalam menentukan apakah model ECM tersebut sesuai dengan spesifikasi dan syarat kesahihan, yaitu variabel ECT (Error Corresction Term), perlu dilihat terlebih dahulu sebelum melanjutkan ke pengujian berikutnya. Jika nilai 
koefisien ECT menunjukkan signifikansi pada tingkat kepercayaan 95\% ( $\alpha 5 \%$ ) dan menunjukkan tanda positif yang terletak pada $0<E C T<1$, maka dapat disimpulkan bahwa model persamaan yang digunakan memenuhi syarat kesahihan suatu model dinamis ECM.

Secara umum semua hasil estimasi ECM diatas menunjukkan bahwa model yang digunakan telah memenuhi kriteria kesahihan spesifikasi model ECM. Hasil Persamaan I memperlihatkan nilai ECT sebesar 0,917101 dengan nilai probabilitas 0,0000 menandakan bahwa model persamaan tersebut memenuhi kriteria spesifikasi model ECM yang sahih.

\section{Uji Ekonometrik}

1. Uji Multikolinearitas

Dari Hasil uji, nilai korelasi diantara variabel bebas sangat kecil dan lebih kecil dari adjusted r2 yaitu sebesar 0,60. Dengan demikian disimpilkan bahwa model tidak terkena masalah multikolinearitas

\section{Uji Autokorelasi}

Dari hasil estimasi model didapat nilai $R^{2}$ ( $R$-squared) sebesar kemudian nilai $R^{2}$ tersebut dimasukkan kedalam rumus sehingga didapat nilai $(\tau-2) R^{2}=(55-2)$ * $0,050336=2,667808$. Sedangkan nilai $X^{2}(2)$ dengan $\alpha 5 \%$ sebesar 5,99147 . Dengan demikian, berdasarkan hasil uji B-G, maka hipotesis nol $\left(\mathrm{H}_{0}\right)$ yang menyatakan bahwa $\rho_{1}=\rho_{2}=0$ diterima karena nilai $X^{2}$ hitung lebih kecil dari nilai $X^{2}$ tabel, atau dengan kata lain masalah autokorelasi tidak ditemui dalam model persamaan empiris yang digunakan.

\section{Uji Statistik}

a. Ujit

Hasil uji t dalam penelitian ini dapat dijelaskan secara lengkap sebagai berikut:

1) Koefisien regresi dari konstanta diperoleh nilai t hitung -0.417108 dengan nilai probabilitas 0,8712 ternyata lebih besar dari nilai $t$ tabel $-2,0117$, hal tersebut menunjukkan bahwa variabel konstantan tidak berbeda dengan nol atau berarti tidak signifikan pada tingkat $\alpha 5 \%$.

2) Koefisien regresi variabel DSBI diperoleh nilai t hitung sebesar -2.825129 dengan probabilitas 0,0057 dimana nilai tersebut lebih besar dari nilai t tabel pada $\alpha 5 \%$; 2,0117 . Hal tersebut menunjukkan bahwa variabel suku bunga SBI jangka panjang secara signifikan tidak berbeda dengan nol, artinya variabel DSBI secara individu berpengaruh secara signifikan terhadap variabel dependen inflasi (DINF) pada tingkat $\alpha 5 \%$.

3) Koefisien regresi dari variabel DSPREAD diperoleh nilai t hitung sebesar -0,135634 dengan nilai probabilitas 0,8924, lebih besar dari nilai t tabel sebesar $-2,0117$. Maka variabel DSPREAD secara signifikan tidak berbeda dengan nol, artinya 
variabel spread suku bunga jangka panjang secara individu tidak berpengaruh secara signifikan terhadap variabel dependen DINF pada tingkat $\alpha 5 \%$.

4) Koefisien regresi dari variabel DKURS menunjukkan nilai t hitung sebesar 0,977649 dengan nilai probabilitas 0,3310 ternyata lebih kecil dari nilai t tabel pada $\alpha 5 \%$ yaitu 2,0117. Maka variabel DKURS secara signifikan tidak berbeda dengan nol, artinya variabel nilai tukar rupiah terhadap dollar AS secara individu tidak berpengaruh secara signifikan terhadap variabel DINF pada tingkat $\alpha 5 \%$.

5) Koefisien regresi dari variabel $\mathrm{SBI}(-1)$ diperoleh nilai t hitung sebesar -6.4598 dengan nilai probabilitas 0,0000 lebih kecil dari nilai t tabel pada $\alpha 1 \%$ yaitu 2,6846. Maka variabel SBI(-1) secara signifikan berbeda dengan nol, artinya variabel suku bunga SBI jangka pendek secara individu berpengaruh secara signifikan terhadap variabel dependen DINF pada tingkat $\alpha 1 \%$.

6) Koefisien regresi dari variabel $\operatorname{SPREAD}(-1)$ diperoleh nilai $t$ hitung sebesar 5.861781 dengan nilai probabilitas 0,0000 lebih kecil dari nilai t tabel pada $\alpha 1 \%$ sebesar $-2,6846$. Maka variabel SPREAD(-1) berbeda dengan nol, artinya variabel spread suku bunga SBI jangka pendek secara individu berpengaruh secara signifikan terhadap variabel dependen DINF pada tingkat $\alpha 1 \%$.

7) Koefisien regresi dari variabel KURS(-1) diperoleh nilai t hitung sebesar -8.698704 dengan nilai probabilitas 0,0000 lebih kecil dari nilai t tabel pada $\alpha 1 \%$ sebesar 2,6846. Maka variabel KURS(-1) berbeda dengan nol, artinya variabel nilai tukar rupiah terhadap dollar AS jangka pendek secara individu berpengaruh secara signifikan terhadap variabel dependen DINF pada tingkat $\alpha 1 \%$.

b. Uji F

Hasil estimasi dengan metode ECM, untuk Persamaan I diperoleh nilai F-hitung sebesar 11.83731 dengan probabilitas signifikansi sebesar 0,0000 , lebih besar daripada nilai Ftabel 0,3283 pada tingkat $\alpha 1 \%$. Hal tersebut menunjukkan bahwa semua variabel independen secara serentak berpengaruh secara signifikan terhadap variabel dependen pada tinngkat $\alpha 1 \%$ atau derajat keyakinan $99 \%$.

c. $\quad$ Uji $R^{2}$ (Koefisien Determinasi)

Uji $R^{2}$ ditujukan untuk menghitung seberapa besar variasi dari variabel dependen dapat dijelaskan oleh variasi dari variabel independen. Nilai statistik koefisien determinasi yang telah disesuaikan (adjusted R-squared) yang diperoleh dari hasil estimasi Persamaan I adalah sebesar 0,646607. Ini berarti bahwa 64,66 persen variasi variabel inflasi dapat dijelaskan oleh variasi dari variabel independen yang dimaksudkan dalam model, sedangkan sisanya dijelaskan oleh variasi dari variabel lain yang tidak termasuk dalam model.

\section{KESIMPULAN}


Daripersamaan I, variabel penjelas secara bersama-sama mempengaruhi tingkat inflasi yang ditunjukkan oleh signifikansi pada uji $\mathrm{F}$ pada $\alpha 5 \%$. Hal tersebut menunjukkan bahwa secara umum variabel independen mempengaruhi perubahan tingkat inflasi. Variabel penjelas tingkat suku bunga SBI, spread suku bunga dan nilai tukar, mempu menjelaskan variasi perubahan pada tingkat inflasi. Suku bunga Sertifikat Bank Indonesia (SBI) dalam jangka pendek mempengaruhi tingkat inflasi secara signifikan pada tingkat $\alpha 1 \%$. Dalam jangka panjang suku bunga SBI tidak berpengaruh secara signifikan terhadap variabel tingkat inflasi pada $\alpha 5 \%$. Koefisien jangka panjang diperoleh melalui penurunan dari koefisien jangka pendek yang menunjukkan signifikansi dan disesuaikan dengan koefisien koreksi kesalahan (ECT).

Dari kondisi tersebut dapat ditarik kesimpulan bahwa koefisien hubungan jangka panjang antara suku bunga SBI dengan tingkat inflasi yang dihasilkan dalam penelitian berdasarkan data ekonomi makro Indonesia, sesuai dengan dugaan mula-mula (hipotesis) dan teori ekonomi yang ada, yaitu terdapat hubungan yang berkebalikan (negatif) antara suku bunga dengan tingkat inflasi. Spread suku bunga SBI (3 bulan - 1 bulan) berpengaruh terhadap tingkat inflasi jangka pendek secara signifikan pada $\alpha 5 \%$. Dalam jangka panjang spread suku bunga SBI tidak signifikan dalam mempengaruhi tingkat inflasi pada $\alpha 5 \%$. Koefisien jangka panjang diperoleh melalui penurunan dari koefisien jangka pendek yang menunjukkan signifikansi dimana disesuaikan dengan koefisien koreksi kesalahan. Koefisien jangka panjang menunjukkan hubungan yang sesuai dengan dugaan mula-mula, yaitu hubungan secara positif. Nilai tukar rupiah per dollar AS, berpengaruh secara signifikan terhadap tingkat inflasi jangka pendek pada tingkat kesalahan 5\%. Dalam jangka panjang nilai tukar rupiah tidak berpengaruh secara signifikan terhadap tingkat inflasi pada $\alpha 5 \%$. Nilai koefisien simulasi jangka panjang nilai tukar rupiah per dollar AS (kurs) diturunkan melalui koefisien jangka pendek setelah disesuaikan dengan koefisien koreksi kesalahan.

Dari persamaan II, secara khusus menekankan pada hubungan/ predikatabilitas spread suku bunga SBI terhadap inflasi IHK, diperoleh temuan bahwa variasi spread suku bunga dapat menjelaskan variasi inflasi IHK untuk jangka waktu 8 dan 12 bulan kedepan. Koefisien jangka panjang yang diperoleh melalui penurunan dari koefisien jangka pendek, menunjukkan bahwa hubungan antara spread suku bunga SBI dengan inflasi IHK sesuai dengan hipotesis awal, yaitu terdapat hubungan positif. Jangka waktu 8 dan 12 bulan tersebut dapat dijadikan indikasi awal adanya kemampuan prediksi spread suku bunga SBI terhadap tingkat inflasi IHK di masa depan.

\section{DAFTAR PUSTAKA}

Achjar Iljas (2002). Perkembangan Ekonomi Moneter Terkini dan Arah Kebijakan Moneter Bank Indonesia. CD-ROM Bank Indonesia.

Bank Indonesia. (2003). Penjelasan Atas Undang-Undang Republik Indonesia Nomor 23 Tahun 1999 Tentang Bank Indonesia.

Bank Indonesia. (2002). Laporan Tahunan Bank Indonesia 2002.

QE Journal | Vol.01 - No.02 - 38 
Bank Indonesia. (2001). Laporan Tahunan Bank Indonesia 2001.

Blanchard, Oliver (2000). Macroeconomics $2^{\text {nd }}$ Edition. Prentice-Hall.

Cargil, Thomas F. (1991). Money, The Financial System and Monetary Policy $4^{\text {th }}$ Edition. Prentice-Hall International Edition.

Dornbusch, Rudriger and Fischer, Stanley (2000). Macroeconomics. Irwin/McGraw-Hill.

Erwin Haryono dan Triono Widodo (2002). Implementasi Kerangka Kerja Kebijakan Moneter Bank Indonesia Menurut UU No. 23 Tahun 1999. CD-ROM Bank Indonesia.

Gujarati, Damodar N. (2003). Basic Econometrics $4^{\text {th }}$ Edition. MacGraw-Hill.

Kotlan, Victor (1999). "The Term Structure of Interest Rates and Future Inflation". Eastern European Economics, Vol. 37, No. 5, September-October 1999, pp. 3651.

http://econpapers.hhs.se/paper/wpawuwpma/0004014.htm

Kotlan, Victor (2001). "Monetary policy and the term structure of interest rates in a small open economy - a model framework approach". Eastern European Economics.

http://econpapers.hhs.se/paper/wpawuwpma/0110003.htm

Kozicki, Sharon (1998). "Predicting Inflation With The Term Structure Spread". Federal Reserve Bank of Kansas.

Mankiw, N. Gregory (2000). Macroeconomic. McGraw-Hill.

Muana Nanga. 2001. Makroekonomi: Teori, Masalah dan Kebijakan. Jakarta : PTRaja Grafindo Persanda.

Mulyanto (1999). Regresi Model Dinamis ECM.

Rivera-Batiz, Francisco A. and Rivera-Batis, Luis A. (2001). Internationl Financial Economic and Open Macroeconomic. Prentice-Hall, New Jersey.

Sadono Sukirno (2000). Makroekonomi Modern: Perkembangan Pemikiran Dari Klasik Hingga Keneysian Baru. Jakarta: Rajawali Press.

Badan Pusat Statistik, Indikator Ekonomi, Beberapa Edisi, Jakarta.

Bank Indonesia, Laporan Mingguan, Beberapa Edisi, Jakarta. 